\title{
FROM IDEOLOGICAL FUNDAMENTALISM TO CRITICAL OPENNESS: AN URGENT CHALLENGE FOR RELIGION AND SCIENCE
}

\author{
Marek Słomka \\ The John Paul II Catholic University of Lublin, Poland
}

\begin{abstract}
On October 22, 1996, John Paul II addressed his profound message to the Pontifical Academy of Sciences on the theory of evolution. The Pope wrote that "it is remarkable that this theory has had a progressively greater influence on the spirit of researchers, following a series of discoveries in different scholarly disciplines. The convergence in the results of these independent studies constitutes in itself a significant argument in favor of the theory." Nevertheless, many believers disagree with the abovementioned claim, especially with regard to biological evolution. Some of them present a way of thinking that was proposed by the authors of "The Fundamentals" over 100 years ago. That is why I argue that there is still a strong need for scientific education among Christians to avoid mistakes known from the past and build a new open and creative dialogue between religion and science. It was promoted by John Paul II in his official letter to the director of the Vatican Observatory dated June 1, 1988.
\end{abstract}

\section{INTRODUCTION}

The history of science proves how many habits and the irrational fear of what is new affect the fate of innovative scientific ideas. This paper aims to show that it is indeed important for scientific development to draw upon great intellectual traditions and keep re-assessing the particular solutions in a given sphere of knowledge that these traditions put forward. What is more, the conceptual, methodological, and objective transformations taking place in philosophy and the natural sciences can become genuine grounds for the development of Christian thought. However, this does not mean that we should question the foundations of already established doctrine, but rather that we should avoid doctrinal fundamentalism. Such fundamentalism is based on undermining scientific achievements and delimiting the valuable forms of theism to the narrow sphere of classical approaches.

\section{TELEOLOGICAL HABITS}

The first half of the $16^{\text {th }}$ century was a period of great transformation in many 
parts of the world. In East-Central Europe, a great Polish astronomer - Nicolaus Copernicus - examined celestial bodies. Based on patient observations and ingenious ideas, Copernicus prepared De Revolutionibus Orbium Coelestium - a book that forever changed the view of the world. Thanks to courageous scholars like Galileo and Copernicus, it has been discovered how effective and worthwhile it is to search for the causes of natural phenomena.

Unfortunately, the scientific revolution, which then took place in physics and astronomy (and was authored mostly by people within the Church), did not lead to analogical changes in reflection upon biotic systems. An attachment to teleological reasoning - rooted in history, philosophical authorities, and combined with a vivid means of expression - in many circles led to thinking that descriptions of various systems as perfectly pursuing a predetermined purpose could serve as inviolable models. Theistically-oriented advocates of such an approach claimed that the order visible in animate nature takes its source in God's plan for the world. Uncritical emphasis on the interventionist influence of the Creator on the particular course of evolution prevented the posing of open questions on the causes of natural phenomena and blocked the development of many aspects of Christian thought - especially the concept of God's relationship with the world. ${ }^{1}$

In teleology-dominated circles, it was stressed that the structure and development of the universe were precisely defined in the plan of the Creator. For this reason, the direction of particular physical processes towards their appropriate goal was perceived for entire centuries as an expression of the rationality introduced to the world by the Divine Logos. As late as the $19^{\text {th }}$ century, studies on the functioning of nature contained statements on the functioning of nature that water reaches its maximum density in the temperature of $-4^{\circ} \mathrm{C}$ in order to enable the living organisms dwelling in the depths of water to survive harsh winters. ${ }^{2}$

In the first half of the $19^{\text {th }}$ century, teleological interpretations were mostly formulated in the British Isles. This can seem surprising in view of the number of scientific discoveries made in England during that same time in various areas of knowledge. Unfortunately, the attachment to physico-theology lingered, and its advocates searched the natural sciences for arguments for God's existence and providential power in the world. Thus, on the one hand, scholars proudly emphasized the discovery of a principle uniting all natural phenomena, namely the law of the conservation of energy. On the other hand, a thesis was formulated that the harmony of the world can only be fully understood in the light of theism. Arguing that mechanical, chemical, and biological phenomena alike are based on converting kinetic energy into heat. As cited in Order out of Chaos (Ilya Prigogine and Isabel Stengers 1984, 108-109), James Joule wrote:

Thus it is that order is maintained in the universe - nothing is deranged, nothing ever lost, but the entire machinery, complicated as it is, works smoothly and harmoniously. Moreover, though ... everything may appear complicated and involved in the apparent confusion and intricacy of an almost endless variety of causes, effects, conversions, and arrangements, yet is the most perfect regularity preserved - the whole being governed by the sovereign will of God. 
Teleological interpretative patterns encouraged scholars to search for the manifestations of Divine design everywhere. The shape of the human nose was justified with the ease with which it holds glasses and the number and position of the fingers with the opportunity they give to hold a pen comfortably. The regularities occurring within a population of organisms was explained analogically. The similar number of newborns of both sexes was interpreted as a manifestation of a harmony designed by God so that - on reaching maturity - every man could easily find a life partner. The purpose and order governing the world were treated as the expression of a Divine project. This was presented in the most detailed and literary manner by William Paley in his book Natural Theology or Evidence of the Existence and Attributes of the Deity (1802), who formulated a classically shaped argument for the existence and action of God, thus based on nature's purposiveness. ${ }^{3}$ The theory introduced by Paley was enchanting in its simplicity and order. In its light, God was viewed as the equivalent of the highest engineer, personally running the processes of nature.

\section{THE ABSOLUTIZATION OF IMMUTABILITY}

While looking for reasons for such persistent attachment to simplified interpretations of natural phenomena, it is worth underlining the influence of intellectual patterns of a more general nature. One of these patterns was the longstanding conviction that any change regarding the view of the world should be treated as a scientific regression. Such reasoning regarded both ontological and epistemological questions. On the one hand, immutability was absolutized within a universal structure that had a permanently fixed hierarchy of beings, at the top of which the Absolute presided - unchanging in every respect. On the other hand, the inviolable canon of truths, lying within the sphere of specific knowledge, was dogmatized. Episteme and Doxa were treated as radically separate fields of human cognition, the former remaining entirely fixed and allowing for a precise definition.

The history of the absolutization of immutability in various disciplines dates back to the time of Greek philosophy. For Plato, this constituted a fundamental trait of what is most real. For Aristotle, the height of the immutability paradigm came with the description of God as being devoid of knowledge of the changing world since this might endanger His very mind with change and would thus undermine Divine perfection itself. The only possible subject of God's reflection was himself.

The position Stagirite held concerning the fields of philosophy, and natural science was so strong that the theory he put forward was absolutized in many intellectual circles - irrespective of the given epoch. Such an attitude regarded not only the reflection upon the nature of God but also upon the world He created. The world's order predetermined eternal harmony, both on the level of celestial structures, governed by their own immutable laws, as well as the sphere of beings existing on earth. The borders between species and breeds established according to God's will were to remain forever inviolable. ${ }^{4}$

The order governing the immutable heavens was of a necessary character in Aristotelian physics. This was guaranteed by the concept of a natural place, which 
allowed scholars to concede that subtle matter belongs to superlunary regions. In the light of the above, justifying why down rises up and why stones fall was not troublesome since the earth was proper for the non-ethereal matter. The simplicity of the description of physical phenomena implied an analogous order among animals. The basis for such a classification was seen in the four elements which made up the world. After all, everyone should know - as scholars noted - that air is the habitat of birds and water is the habitat of fish (see Michał Heller and Józef Życiński 1996, 37).

Uncritically viewing the existing picture of the world and the deep conviction that it cannot be different are the main reasons for the long-term domination of the system elaborated by Aristotle who - to express due respect - was simply called the Philosopher. The theory he developed provided a sense of particular intellectual security and comfort (Edward Grant 1977, 62). The authority of Aristotle had been so great for so long that those scholars desiring to protect their good position in the world of science emphasized the number of times they read his Metaphysics. Stagirite himself ascertained the inviolability of his place in the circle of the most renowned researchers of nature by pointing out that his cosmology is not only true but also has no rational alternative. Fundamental scientific problems seemed to have been clarified once and for all. Referring to Aristotle's writings, St. Albert the Great - the mentor of St. Thomas Aquinas - stressed in the 13th century that a person who claims that there is no distinction between celestial spheres, which surround one another, and that everything is a unity and a continuity, does not know what he says and is an ignoramus in the issues of the heavens. ${ }^{5}$

\section{DARWIN AS A THREAT}

After the scientific revolution carried out in the fields of astronomy and physics thanks to the revelatory deliberations and insightful research done by Copernicus, Galileo, and Newton, one could expect that the great range of empirical data combined with good theories would allow for the final closing of the epoch in which immutability was absolutized. Unfortunately, this did not happen, with a distinctive example of this being the fate of biological evolutionism. Even though many years had passed from the time of the breakthrough of the reflections on inanimate nature to the famous publication of Charles Darwin's The origin of species (1959), bad habits and prejudice were still a frequent and crucial aspect of the intellectual outlook of those who criticized the theory of natural selection.

The reactions to Charles Darwin's publications clearly point out that identifying mutability with imperfection in various disciplines generates strong ontological declarations. The end of the $19^{\text {th }}$ century was a time of radical social reactions based on the perception of a threat in the idea stressing the importance of mutability in nature. On the grounds of more popular studies concerning evolutionism, scholars tried to prove that since everything is subject to change and the boundaries between species are becoming blurred, striving to find lasting principles in ethics and morality will become very difficult. As a consequence, people began to be threatened with relativism, which was said to manifest itself in the lack of immutable values in both personal and public life (Słomka 2004, 52). 
In the USA, the fear of this new scientific paradigm was one of the reasons for the creation of the editorial series entitled The Fundamentals. This series appeared between 1910 and 1915 in some American academic centers as a reaction to the destruction of cultural foundations by relativism, supposedly generated by new scientific findings. Some concern was obviously psychologically justified since the $19^{\text {th }}$ century indeed brought essential changes in the way the world had been perceived so far. However, as Józef Życiński (2011, 32-44) observed, what posed the real problem was the fact that discarding the outdated and false concept of animate nature was found unacceptable, and any modifications in this regard were perceived as a threat to the entirety of culture.

Fundamentalists were most radically opposed to the theory of evolution. Since some of its advocates claimed that the rule of the strongest is simply inscribed in human nature, criticism of Darwinism appeared as the only way to defend Christian humanism. Such a stance was evident both in publications regarding the relationship between science and religion, as well as in everyday social life. In 1925, in the American state of Tennessee, John Scopes was put on trial and fined for propagating Darwin's theory. The slogan behind his prosecutors' reasoning was one spread by many of the fundamentalists from Dayton, namely: "Only one can prevail Christianity or the theory of evolution." Another example of the aversion felt towards this new science was the introduction of creationism in its most extreme version to the schools of Arkansas and Louisiana, thus treated as a counterbalance to teaching the biological theory of evolution. In such an environment, the division between science and religion only deepened, and Christian doctrine was thought to be completely incompatible with new theories and their subsequent interpretation of nature (Drees 2000, 66).

Therefore, evolutionism and creationism were treated in the categories of a disjunctive proposition. This was not an effect of a content-oriented approach but rather the effect of historical conditioning (Kazimierz Kloskowski 1999, 103-105). The critics of Darwinian evolutionism repeatedly named their views' creationism.' The creationist movement, striving to sound credible outside of religious circles, referred to the statements uttered by some natural scientists themselves and used these statements in a manipulative manner to promote their own anti-evolutionary message. Such was the case of William Bateson, who continued to examine Mendelism and conducted research in the field of sex determination until he died in 1926. His opinion of scientists not having discovered the way in which evolution functions was treated as taking a stance in support of creationism. The British biologist unsuccessfully protested against the identification of his views with the ideology of the movement, which intended to remove Darwinism from American school curricula.

The consequences of the above-presented prejudice also manifested themselves in subsequent decades. In the second half of the $20^{\text {th }}$ century, the desire to defend the unalterable values of the imaginary threat of Darwinism assumed the form of so-called creation science (Merryl Wyn Davies 2002, 73-83 and Roger Lewin 1982, 142-144). ${ }^{6}$ A telling example of the irrational fear that the socio-moral sphere is about to be permeated with the idea of evolutionary mutability is provided in a text from Tim LaHaye $(1975,5)^{7}$ in which it is stated that the theory of evolution is 
...the philosophical foundation for all secular thought today, from education to biology and from psychology through the social sciences. It is the platform from which socialism, communism, humanism, determinism, and one-worldism have been launched ... Accepting man as an animal, its advocates endorse animalistic behavior such as free love, situation ethics, drugs, divorce, abortion, and a host of other ideas that contribute to men's present futility and despair... It has ... devastated morals, destroyed man's hope for a better world, and contributed to the political enslavement of a billion or more people.

Using Darwin's legacy as a threat, even today, the theory of evolution is portrayed as a danger to Christian anthropology. In 1998, George Sim Johnston published a book entitled Did Darwin get it right? Catholics and the Theory of Evolution. In this work, the author makes predictions that can hardly be justified in a rational way. In Johnston's opinion, there is a great chance of Darwin soon sharing the fate of Marx and Freud by joining the ranks of long-forgotten ideologists. Placing the significance of empirical evidence in opposition to Darwinism, the American fundamentalist claims that the rejection of Darwinism will open a path to traditional metaphysics. The publication contains encouragement to put the Origin of Species back on the shelf and open works by Aristotle or St. Thomas Aquinas. Johnston $(1998,12)$ wrote:

Modern man will no longer be obliged to view himself as a shifting, accidental thing with no more dignity than a stone or jellyfish. Biology will be freed from the straitjacket of mechanistic philosophy and, more importantly, the doctrine of creation, whose eclipse in recent generations has had a devastating effect on Christian apologetics, will be restored to its rightful place.

In the context of the above, it is worth pointing out that there are no substantive reasons for linking biological evolutionism to the mechanical philosophy. What is more crucial, however, is the question of man's place in nature. The theory of evolution supposedly views our species as degraded to the level of a simple living organism or even a physical object. The postulated way to restore the appropriate status of the human being is to reject contemporary scientific discoveries and replace them with metaphysical reflection. Such suggestions should be evaluated in an unambiguously critical way because they are not an expression of a reliable presentation concerning the fundamental principles of the biological theory of evolution and serve only as a means of consolidating the basics of anti-scientific fundamentalism.

There are many radical statements to be found in Johnston's (1998, 100, 101, 103) publication. In his opinion, it is "scarcely possible to exaggerate the subsequent influence of Darwin's theory on Marxist thought - and therefore on the crimes committed, and still to be committed, by Marxist regimes." Subsequently, readers can come across claims of the negative impact that Darwin had on capitalism and suggestions of the influence of evolutionism on the rise of national socialism even 
though Johnston underlines that looking for the causes of the outbreak of world conflict in the theory of evolution is an oversimplification. At the same time, he states that there is only "a short step from Darwin to the gas ovens and abortion mills." Equally irrational statements can be found in many creationist texts written to a significant extent under the influence of Henry M. Morris's (1974) Troubled waters of evolution.

\section{ADAM, EVE, AND EVOLUTION}

In Christian circles, intellectual fundamentalism was often a result of the "literalist" reading of some Biblical texts - especially those concerning the creation of the world and the first stages of its development. Anti-evolutionary creationism put a strong emphasis on the opposition between the biblical and the scientific picture of the creation of man. However, this would only be relevant and justifiable if the Book of Genesis was a research source in the field of anthropogenesis. The Catholic Church excludes such a possibility, pointing out that the first chapters of the Bible cannot be properly understood without critical historical study. Moreover, many documents contain a call for taking account of scientific research during the interpretation of biblical texts. This is significant not only for biblical studies but for theology as such. ${ }^{8}$

The value of interdisciplinary cooperation for the overcoming of mutual antagonism was stressed by John Paul II (1993) ${ }^{9}$ during the presentation of the document entitled The Interpretation of the Bible in the Church (II.B.1), with this document having been prepared by the Pontifical Biblical Commission. Linguistic research and contemporary achievements in hermeneutics lead to the acknowledgment of the possibility that some biblical texts may be polysemic. This does not imply that efforts undertaken to determine the precise meaning of a given fragment of the Bible are groundless. On the contrary, the work done to establish the proper sense of a given text remains a crucial task. Nevertheless, in finding such a meaning, it is essential that we take into account and scrutinize the literary conventions in which a particular text was written.

The pontifical document stresses the plurality of biblical interpretation methods. By bearing in mind the frequently complicated exegesis methods, it needs to be remembered that the interpretation of Holy Scripture has to be done from the theological perspective. In this context, the main aim of biblical interpretation is to deepen religious belief, and not merely to take advantage of the text for apologetic reasons or - even more so - to limit scientific research. After all, the Bible teaches us - as Galileo (1978, 128135) rightly noticed - how to go to Heaven, and not how the heavens go.

An essentially different interpretative style is assumed by those who translate biblical texts word for word, thinking that the main aim of exegesis is to arrive at the so-called literalist sense. Among fundamentalists who promote this approach, in order to understand the Bible correctly, both the historical-critical method and all the other scientific methods have to be rejected. In this way, the biblical description of the world becomes the equivalent of a scientific interpretation of the world. For instance, scientific caricatures in the shape of creation science are given the status of a Christian worldview. ${ }^{10}$ 
In light of the above, it is very significant to notice the instrumental treatment and interpretation of the first chapters of the Book of Genesis. The description of the creation of man is not easily understandable because at least two different traditions are included in the text. Publications that facilitate a proper interpretation of this section of Holy Scripture point out, however, that the text itself is not of a historical dimension. The numerous metaphors found within the first chapters of the Book of Genesis suggest the need to treat it as a source of the symbolic content of profound theological meaning. For this reason, attempts at a superficial reading of this part of the Bible - as if it was a course book in scientific and historical knowledge concerning the origins of the universe and our species - are all the more confusing.

One of the most renowned Polish scholars specializing in biblical studies, Rev. Prof. Józef Homerski (1998, 29-30), stressed:

The biblical description of the creation of man is not a historical record of the event but a piece of figurative information aiming at drawing our attention to the fact that this event is essentially very mysterious, its beginning being impossible to determine ... The song of the creation of man is neither critical of other interpretations of this mystery, nor does it impose its own point of view. In doing so, it helps to understand that the path to scientific research on the creation of man and the world is open ... What the song of the creation of the first human couple conveys refers to every human being, whoever they are and wherever they live. However, it also suggests that God is not only the God of man. He is the God of all creation ... Nevertheless, it cannot be merged by force with our own ideas of creation, not to risk the danger of a faulty interpretation.

Thus, it is a mistake to look for traces of the first humans' history in the pages of the Book of Genesis. This text's profound meaning does not imply that the events recounted here took place in time and space. The previously-mentioned document issued by the Pontifical Biblical Commission reminds us that such biblical texts do not belong to the historical genre but are a product of human imagination. (Cf. The Interpretation of the Bible in the Church, II. B.1). The same document contains strong words of criticism addressed to fundamentalists denying the above principles. The manner in which they present certain truths, e.g., Biblical Inspiration or the Inerrancy of the Word of God, is, in fact, ideology and is contradictory with the proper reading of Scripture. Fundamentalists are not interested in the literary forms and iconic ways humans think, as exemplified in biblical texts. Fundamentalists consider historical "everything that is reported or recounted with verbs in the past tense, failing to take the necessary account of the possibility of symbolic or figurative meaning" (Cf. The Interpretation of the Bible in the Church, I. F).

Biblical fundamentalism narrows research perspectives, and it absolutizes ancient cosmology only because its traces can be found in the Scripture. In the 1988 letter to the director of the Vatican Observatory, John Paul II warned against assuming such an approach, for it makes the dialogue between theology and natural science more complicated. In his message, the Pope posed numerous rhetorical questions expressing 
the necessity to take account of contemporary scientific thought in theological studies. Pope John Paul II (1988) wrote:

If the cosmologies of the ancient Near Eastern world could be purified and assimilated into the first chapters of Genesis, might not contemporary cosmology have something to offer to our reflections upon creation? Does an evolutionary perspective bring any light to bear upon theological anthropology, the meaning of the human person as the imago Dei, the problem of Christology - and even upon the development of doctrine itself? What, if any, are the eschatological implications of contemporary cosmology, especially in light of the vast future of our universe? Can theological method fruitfully appropriate insights from scientific methodology and the philosophy of science?

\section{DOGMAS IN SCIENCE AND RELIGION}

Theological methodology, as well as subject-oriented approaches to Christian doctrine, and even problems of Christology can find enrichment in dialogue with the natural sciences. In the last century, they developed indeed vigorously thanks to the active involvement of many prominent scholars. On the grounds of the developing science, which shaped a dynamic picture of nature, new branches of anthropology, ontology, and theology evolved. Many innovative theories emerged in the favorable environment of fundamental modifications occurring in fields that were previously seen as spheres defined by the inviolability of their elementary assumptions. It eventually was discovered that there are alternative approaches even to classical logic and that the laws of science evolved during a particular stage of long-term cosmic history.

In the last several decades, more and more valuable intellectual postulates have appeared, which, in the studies conducted on the border between science and religion, creatively used the change that occurred in the fixed model of scientific thinking that was used for centuries. ${ }^{11}$ An essential component of these newly formulated ideas was that the difference between the complete immutability of existing models and their relative stability was taken into consideration. There is no doubt that the strength of such immutability is in providing a justified sensation of living in a world where there are certain constant values. On the other hand, being open to change constitutes a significant trait of the human mentality, which otherwise becomes enclosed in a hermetic system of habits and sometimes irrational fear of losing the preserved status quo in any given area.

Examples of being programmatically opposed to the change associated with intellectual regression can be found both among the defenders of religion as well as science enthusiasts. Among many of its various forms, religious fundamentalism also assumes the shape of a standpoint in the light of which the crucial aspects of doctrine have already been definitively determined. Therefore, it is enough for the members of a given religious community to become familiar with these crucial aspects of doctrine, the task of theologians being to help worshippers in the practical application of said elements. However, such a viewpoint remains outside the mainstream of 
contemporary Christian theology, within which it is stressed that alongside the fundamental and fixed dogmatic canon, new and notable forms of the search for conveying religious messages should also be noticed. After all, these new and notable forms develop theological thought, with theological thought relying not solely on the analysis of the output of authors living in the first centuries of Christianity. Today we mention even the so-called evolution of dogmas. ${ }^{12}$

On the grounds of scientific thought, the hermetic intellectual viewpoint is assumed by those who absolutize the existing state of research. This serves as an illustration of an extremely conservative approach to scientific progress combined with the assumption that the essential secrets of the universe have ultimately been discovered. From such a perspective, the future state of research would not be essentially different from the existing one. Among the supporters of scientific dogmatism, we can discern an intellectual attitude essentially similar to the mentality of the critics of biological evolutionism who claimed that changes could only occur within eternally existing species and not between them. ${ }^{13}$

Intellectual fundamentalism excludes the natural development of concepts that do not assume a simple and unchanging expression that is supposed to be fixed once and for all. Both religious doctrines and scientific theories are subject to modifications in the light of which it is not easy to arrive at a definite answer to whether a change has occurred within a substantial element or on the level of secondary details. For this reason, specific conflicts will remain unresolved, and often the only Solomonic solution is to emphasize interpretative pluralism. Such was the fate of research regarding the theory of biological evolution, which itself had many specific elaborations. As a result, some scholars speak of theories rather than the theory of evolution. However, contemporary natural scientists usually refer to one particular theory of evolution and its heterogeneous interpretations, e.g., the stressing of the role of saltation mutation in the process of speciation. ${ }^{14}$

However, it is worth noting that the history of evolutionism provides many examples of a gradually clarified distinction between what can be judged as a crucial component of a new approach to the history of life and the mechanisms governing its changes, and what can become the subject of methodically practiced doubts and further research. In Darwin's time, some scholars estimated the age of the universe to several thousand years and determined the time of the origin of man accordingly. At the same time, paleontologists of that time were already of an entirely different opinion. Even though their calculations soon had to be revised anew, this did not signify a return to previous, common sense opinions, but they called for research to become even more open to evolutionary ideas. ${ }^{15}$

\section{CONCLUSION: THE POPE'S INTELLECTUAL TESTAMENT}

In contemporary times, scientific discoveries occurring in disciplines as far removed as astronomy, biochemistry, and genetics do not grant a reasonable possibility to maintain the anti-evolutionary hypotheses which were formulated in the $19^{\text {th }}$ century. Today, it is commonly assumed that cosmic history can be estimated to billions of years and that our ancestors began moving in an upright position over a 
million years ago. Such data distinguishes the theory of evolution from any form of pseudoscientific substitutes of knowledge inconsistent with the paradigm of presentday science. This was well understood by John Paul II, who, on October 22, 1996, presented his profound message to the Pontifical Academy of Sciences on the theory of evolution. The Pope wrote that it is

...remarkable that this theory has been progressively accepted by researchers following a series of discoveries in various fields of knowledge. The convergence, neither sought nor provoked, of the results of work that was conducted independently is in itself a significant argument in favor of this theory. ${ }^{16}$

The course of events dating back several million years, or even several hundred thousand years, cannot be entirely reconstructed today. However, the search for details in this area still remains a plausible task that could be effectively realized, e.g., thanks to arduous excavation work carried out at African archaeological sites. Scientific criticism asks for a careful formulation of new theses and the subsequent subjecting of them to multiple testing procedures, according to the ideals of the philosophy of science put forward by Karl Popper. Significant components of intellectual culture deserve special protection. Protections should also be given to theological doctrines, which we can use to point to those most valuable and simultaneously fundamental aspects of a given religious system. Nevertheless, there are many aspects of reflection upon God and His interaction with the world, which are worth treating as prone to modification and refinement. Absolute immutability of beliefs does not appear to be necessary to express the essence of a religious message. On the contrary, the idea of a wrongly understood immutability in reference to doctrine is one of the most important reasons for the degeneration of religion. ${ }^{17}$

The theistic interpretation of the functioning of nature and man should also be subject to modifications. After all, present-day studies in this sphere cannot be undertaken from the perspective of a worldview that is several hundred years oldtaking scientific facts into account influences both dogmatic ideas and axiological theories. As far as the latter field is concerned, this is visible, for instance, when the mental state of a perpetrator and the genetic conditioning of his behavior is investigated during the moral assessment of his deeds. However, there is no clear reason why the former of the areas should be programmatically closed off.

Contemporary challenges in the discipline mentioned above were markedly articulated by John Paul II's 1988 letter to the director of the Vatican Observatory. While postulating that Christian thought should be developed in the context of presentday science, Pope John Paul II (1988) wrote that theology "must be in vital interchange today with science ... Theology will have to call on the findings of science ... as it pursues its primary concern for the human person, the reaches of freedom, ... the nature of belief and the intelligibility of nature and history." What is more, he (1988) further added: "The vitality and significance of theology for humanity will, in a profound way, be reflected in its ability to incorporate these findings." 
The Pope suggests that we should consider the above question carefully. After all, theology "is not to incorporate indifferently each new philosophical or scientific theory" (John Paul II 1988). Nonetheless, his Holiness points out: "As these findings become part of the intellectual culture of the time, however, theologians must understand them and test their value in bringing out from Christian belief some of the possibilities which have not yet been realized" (John Paul II 1988). In this context, John Paul II refers to the significant history of the development of theology in the Middle Ages. He (1988) wrote:

The hylomorphism of Aristotelian natural philosophy, for example, was adopted by the medieval theologians to help them explore the nature of the sacraments and the hypostatic union. This did not mean that the Church adjudicated the truth or falsity of the Aristotelian insight since that is not her concern. It did mean that this was one of the rich insights offered by Greek culture, that it needed to be understood and taken seriously and tested for its value in illuminating various areas of theology.

After this insightful analysis, the Pope voices an important plea which explicitly demonstrates that instead of absolutizing Aristotelian thought, it is worth reaching for the research outcomes elaborated by the scientific culture of our own times. John Paul II (1988) wrote: "Theologians might well ask, with respect to contemporary science, philosophy and the other areas of human knowledge, if they have accomplished this extraordinarily difficult process as well as did these medieval masters." Should we have any more doubts as to what the Pope's diagnosis is? He suggests in the same document that there is not enough intense dialogue with contemporary science among the people involved in theological research and theological instruction. "Pursuing them further would require the sort of intense dialogue with contemporary science that has, on the whole, been lacking among those engaged in theological research and teaching" (John Paul II 1988).

Postulating that theology must open to the natural sciences was of fundamental significance for John Paul II. This was not merely one of the lesser questions, secondary to the other problems of the Church that he tried to solve. The Pope (1988) underlined that the matter is urgent because contemporary "developments in science challenge theology far more deeply than did the introduction of Aristotle into Western Europe in the thirteenth century." At the same time, he (1988) claimed: "these developments also offer to theology a potentially important resource." As a consequence, the Holy Father expressed his hope that "the sciences of today, along with all forms of human knowledge, may invigorate and inform those parts of the theological enterprise that bear on the relation of nature, humanity, and God" (John Paul II 1988). May this appeal of Karol Wojtyła live to the fullest extent on the $100^{\text {th }}$ anniversary of his birth.

\section{Acknowledgments:}

The author would like to express his thanks to Monika Metlerska-Colerick for her professional linguistic support. 
The project is funded by the Minister of Science and Higher Education within the program under the name "Regional Initiative of Excellence" in 2019-2022, project number: 028/RID/2018/19, the amount of funding: 11742500 PLN"

\section{NOTES}

1. Some sections of the first part of this article were already published in my monograph Działanie Boga w świecie. Analiza filozoficzna. Lublin: KUL 2018, pp. 13-15 and 224-236 (to be published in English by Bloomsbury in 2021).

2. Cf. M. Morawski, Celowość w naturze. Studium przyrodniczo-filozoficzne, Kraków: Nakładem Przeglądu Powszechnego 1887, p. 31.

3. Cf. Słomka, Marek. 2004. Ewolucjonizm chrześcijański o pochodzeniu człowieka, p. 53.

4. In some aspects of biology, Aristotle carried out very insightful research, e.g., in the field of embryology. We also cannot consider Stagirite as an enemy of empirical science. It needs to be pointed out that many followers of Aristotle's thought dogmatized his reflections in their entirety.

5. St. Albert the Great, Lib. I de caelo et mundo, tract I, chapter 9.

6. The premise of the Creation Science Movement (established in 1932 as the Evolution Protest Movement) included a defense of truth contained in the Bible as opposed to new scientific theories.

7. This radical text is included in Tim LaHaye's introduction to Henry Madison Morris's book entitled: The troubled waters of evolution, San Diego: CreationLife Publishers 1975, p. 5. LaHaye (d. 2016) published more than 80 books. In 2001 "The Evangelical Studies Bulletin" named him the most influential Christian leader in the last quarter-century in the USA. His significance for the American Christian milieu was emphasized in many publications (cf. Thomas Michael Alleman, The 25 Most Influential Evangelicals in America. Tim and Beverly LaHaye, "Time" September 8, 2007).

8. Cf. e.g., John Paul II. 1988. Letter to Reverend George V. Coyne, S.J. http://www.vatican.va/content/john-paul-ii/en/letters/1988/documents/hf_jpii_let_19880601_padre-coyne.html (Accessed: January 12, 2020).

9. Cf. idem, Przemówienie w setna rocznice ogłoszenia Encykliki 'Providentissimus Deus' $i$ w pięćdziesiata rocznice Encykliki 'Divino Afflante Spiritu' (April 23, 1993), w: Papieska Komisja Biblijna, Interpretacja Pisma Świętego w Kościele (Przemówienie Ojca Świętego Jana Pawła II oraz Dokument Papieskiej Komisji Biblijnej), trans. K. Romaniuk, Poznań: Pallottinum 1994, p. 20.

10. Cf. Pontifical Biblical Commission. The Interpretation of the Bible in the Church, I.F.

11. Cf. e.g., Ayala, Francisco J. 2007. Darwin's gift to science and religion, Washington, DC: Joseph Henry Press; Edwards, Denis. 2010. How God acts: Creation, redemption, and special divine action. Minneapolis, MN: Fortress Press.

12. Cf. Balter, Lucjan. 1985. Dogmatów ewolucja, in: Encyklopedia Katolicka (vol. 4), L. Bieńkowski et al. (eds.), Lublin: TN KUL. 
13. Cf. Gutowski, Piotr. 2016. Stare i nowe. Esej o roli jednostkowych podmiotów, zmiany $i$ watpienia $w$ religii, Kraków: Dominikańskie Studium Filozofii i Teologii. p. 72-73.

14. The main division lines that exist in the interpretation of the theory of evolution resulted from the different manners of explaining the mechanism of evolution and the adopted philosophical viewpoints that provided the necessary terminology and methodology for a particular analysis. As a consequence of the great diversity of philosophical systems, fundamentally distinct types of explanation developed, namely: materialistic, reductionist, or spiritualist. Por. M. Słomka, Ewolucjonizm chrześcijański, p. 42.

15. Cf. Życiński, Józef. 2005. Wartości humanistyczne w cywilizacji naukowotechnicznej, "Annales UMCS" 60:2005 sec. E, p. 3. Cf. also: idem. 1990. Paraintelektualne korzenie fundamentalizmu, "Zagadnienia filozoficzne w nauce" 12:1990, pp. 25-37.

16. Cf. John Paul II, Address to the Pontifical Academy of Sciences (October 22, 1996), no. 4, https://www.firstthings.com/article/1997/03/004-theories-ofevolution. Accessed: January 12, 2020.

17. Cf. P. Gutowski, Stare $i$ nowe, p. 91.

\section{REFERENCES}

Alleman, Thomas Michael. 2007. The 25 Most influential evangelicals in America. Tim and Beverly LaHaye. Time: September 8, 2007.

Ayala, Francisco J. 2007. Darwin's gift to science and religion, Washington, DC: Joseph Henry Press.

Balter, Lucjan. 1985. Dogmatów ewolucja. In Encyklopedia Katolicka (vol. 4), Edited by L. Bieńkowski et al. Lublin: TN KUL.

Darwin, Charles. 1959. On the origin of species by means of natural selection or The preservation of favoured races in the struggle for life. London: John Murray.

Davies, Merryl Wyn. 2002. Darwin and fundamentalism. In Postmodernism and Big Science: Einstein. Edited by Dawkins, Kuhn, Hawking, Darwin, R. Appignanesi. Cambridge: Icon Books.

Drees, Willem. 2000. Creazionismo e evoluzione. Concilium. 36: No. 1, 66.

Edwards, Denis. 2010. How God acts: Creation, redemption, and special divine action. Minneapolis, MN: Fortress Press.

Galilei, Galileo. 1978. Letter to Madame Christine of Lorraine, Grand Duchess of Tuscany. In Lettere, Torino: Einaudi: 128-135.

Grant, Edward. 1977. Physical science in the middle ages. Cambridge: Cambridge University Press.

Gutowski, Piotr. 2016. Stare i nowe. Esej o roli jednostkowych podmiotów, zmiany $i$ wątpienia w religii, Kraków: Dominikańskie Studium Filozofii i Teologii.

Heller, Michał and Józef Życiński. 1996. Dylematy ewolucji. Tarnów: Biblos.

Homerski, Józef. 1998. Pieśń o stworzeniu świata, in: Poczatek świata - Biblia a nauka. Edited by Michał Heller and Michał Drożdż. Tarnów: Biblos. 
John Paul II. 1996. Address to the Pontifical Academy of Sciences (October 22, 1996), no. 4, https://www.firstthings.com/article/1997/03/004-theories-of-evolution. Accessed: January 12, 2020.

John Paul II. 1993. Przemówienie $w$ setna rocznice ogłoszenia Encykliki 'Providentissimus Deus' $i$ w pięćdziesiata rocznice Encykliki 'Divino Afflante Spiritu' (April 23, 1993), w: Papieska Komisja Biblijna, Interpretacja Pisma Świętego w Kościele (Przemówienie Ojca Świętego Jana Pawła II oraz Dokument Papieskiej Komisji Biblijnej). Translated by Kazimierz Romaniuk, Poznań: Pallottinum.

John Paul II. 1988. Letter to Reverend George V. Coyne, SJ. http://www.vatican.va/content/john-paul-ii/en/letters/1988/documents/hf_jpii_let_19880601_padre-coyne.html. Accessed: January 12, 2020.

Johnston, George Sim. 1998. Did Darwin get it right? Catholics and the Theory of Evolution. Huntington, Indiana: Our Sunday Visitor Publishing Division.

Kloskowski, Kazimierz. 1999. Filozofia ewolucji i filozofia stwarzania. Vol. 1: Między ewolucja a stwarzaniem. Warszawa: ATK.

LaHaye, Tim. 1975. Introduction in Henry Madison Morris's book: The Troubled Waters of Evolution, San Diego: Creation-Life Publishers.

Lewin, Roger. 1982. Where Is the Science in Creation Science? Science. January 8, 1982 (vol. 215, no. 4529).

Morawski, Marian Ignacy. 1987. Celowość w naturze. Studium przyrodniczofilozoficzne. Kraków: Nakładem Przeglądu Powszechnego.

Morris, Henry M. 1974. Troubled waters of evolution. San Diego, CA: Creation-Life Publishers.

Paley, William. 1802. Natural theology or Evidences of the existence and attributes of the deity. London: R. Faulder.

Pontifical Biblical Commission. The interpretation of the Bible in the church, https://catholic-resources.org/ChurchDocs/PBC_Interp-FullText.htm. Accessed: January 4, 2020.

Prigogine, Ilya and Isabelle Stengers. 1984. Order out of chaos: Man's new dialogue with nature. Toronto - New York -London - Sydney: Bantam Books.

Słomka, Marek. 2004. Ewolucjonizm chrześcijański o pochodzeniu człowieka. Lublin: Gaudium.

Życiński, Józef. 2011. God and evolution: Fundamental questions of Christian evolutionism. Washington, DC: The Catholic University of America Press. 